Supporting Information

\title{
Highly Soluble Indigo Derivatives as Practical Diesel Absorption Markers
}

Sucheera Modsiri ${ }^{\#, 1}$, Prapinporn Pongmaneerat ${ }^{\#, 1}$, Sumana Tawil ${ }^{2}$, Vinich Promarak ${ }^{3}$, Patchanita Thamyongkit, ${ }^{4, *}$

${ }^{1}$ Program in Petrochemistry and Polymer Science, Faculty of Science, Chulalongkorn University, Bangkok 10330, Thailand

${ }^{2}$ Program of Chemistry, Faculty of Science and Technology, Sakon Nakhon Rajabhat University, Sakon Nakhon 47000, Thailand

${ }^{3}$ Department of Material Science and Engineering, School of Molecular Science and Engineering, Vidyasirimedhi Institute of Science and Technology, Wangchan, Rayong 21210, Thailand

${ }^{4}$ Department of Chemistry, Faculty of Science, Chulalongkorn University, Bangkok 10330, Thailand

${ }^{\#}$ Contributed equally to this work *patchanita.v@chula.ac.th

\section{Table of Contents}

Characterization data of compound $\mathbf{1}$ S2-S3

Characterization data of compound $\mathbf{2}$ S4-S5

Characterization data of compound $\mathbf{3}$ S6-S7

Characterization data of compound 4 S8-S9

Characterization data of compound $\mathbf{5}$ S10-S11

Characterization data of compound 6

Standard calibration curves of compound $\mathbf{1}$

Standard calibration curves of compound $\mathbf{3}$

Standard calibration curves of compound 4

Standard calibration curves of compound $\mathbf{5}$

Standard calibration curves of compound 6 
<smiles>CCOc1ccc(N=C2C(=C3Nc4ccccc4N3)NC3CCCCC23)cc1</smiles>
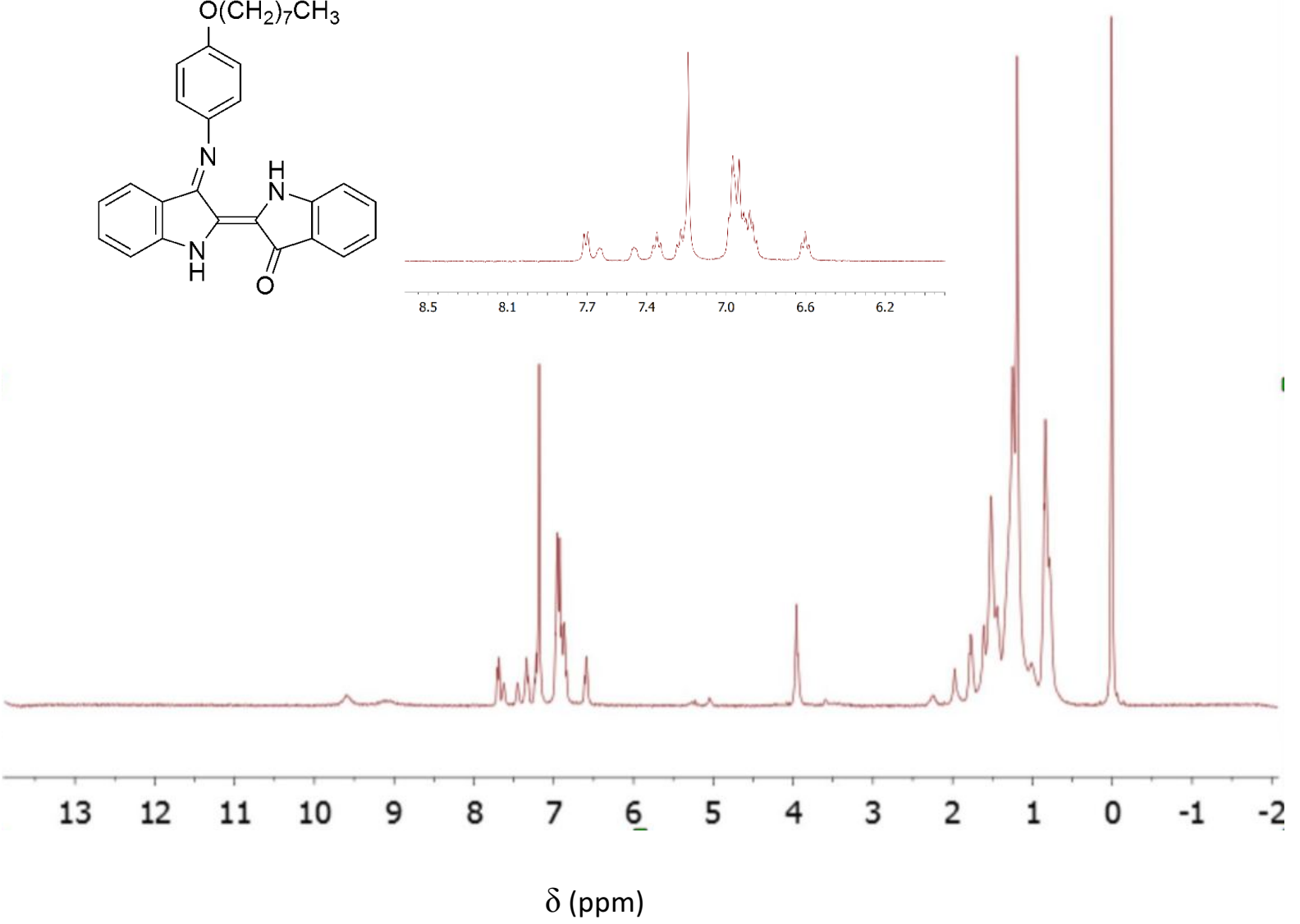

Figure S1. $\mathrm{H}-\mathrm{NMR}$ spectrum of compound $\mathbf{1}$ in $\mathrm{CDCl}_{3}$

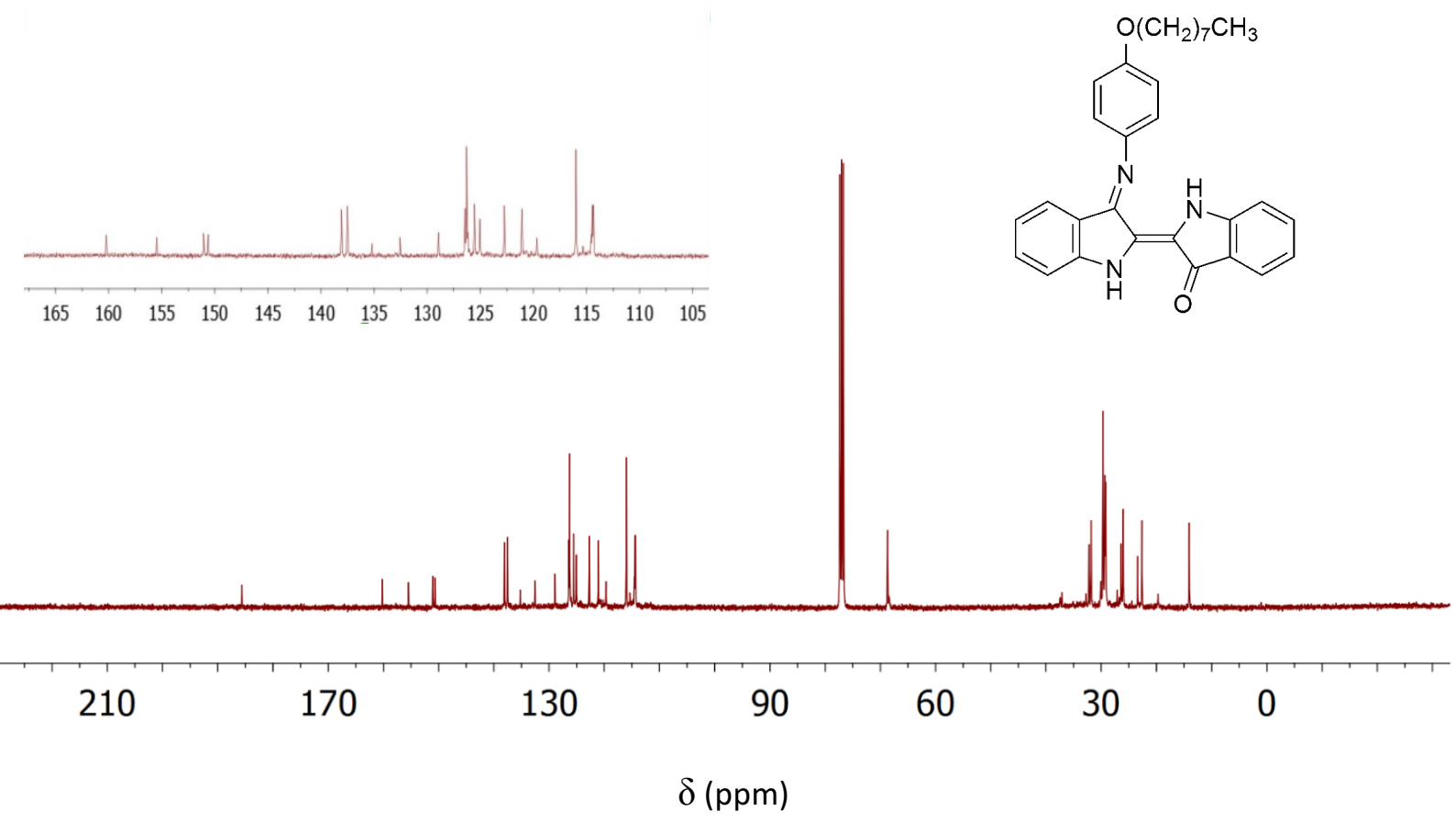

Figure S2. $\mathrm{C}-\mathrm{NMR}$ spectrum of compound 1 in $\mathrm{CDCl}_{3}$ 


\section{Mass Spectrum List Report}

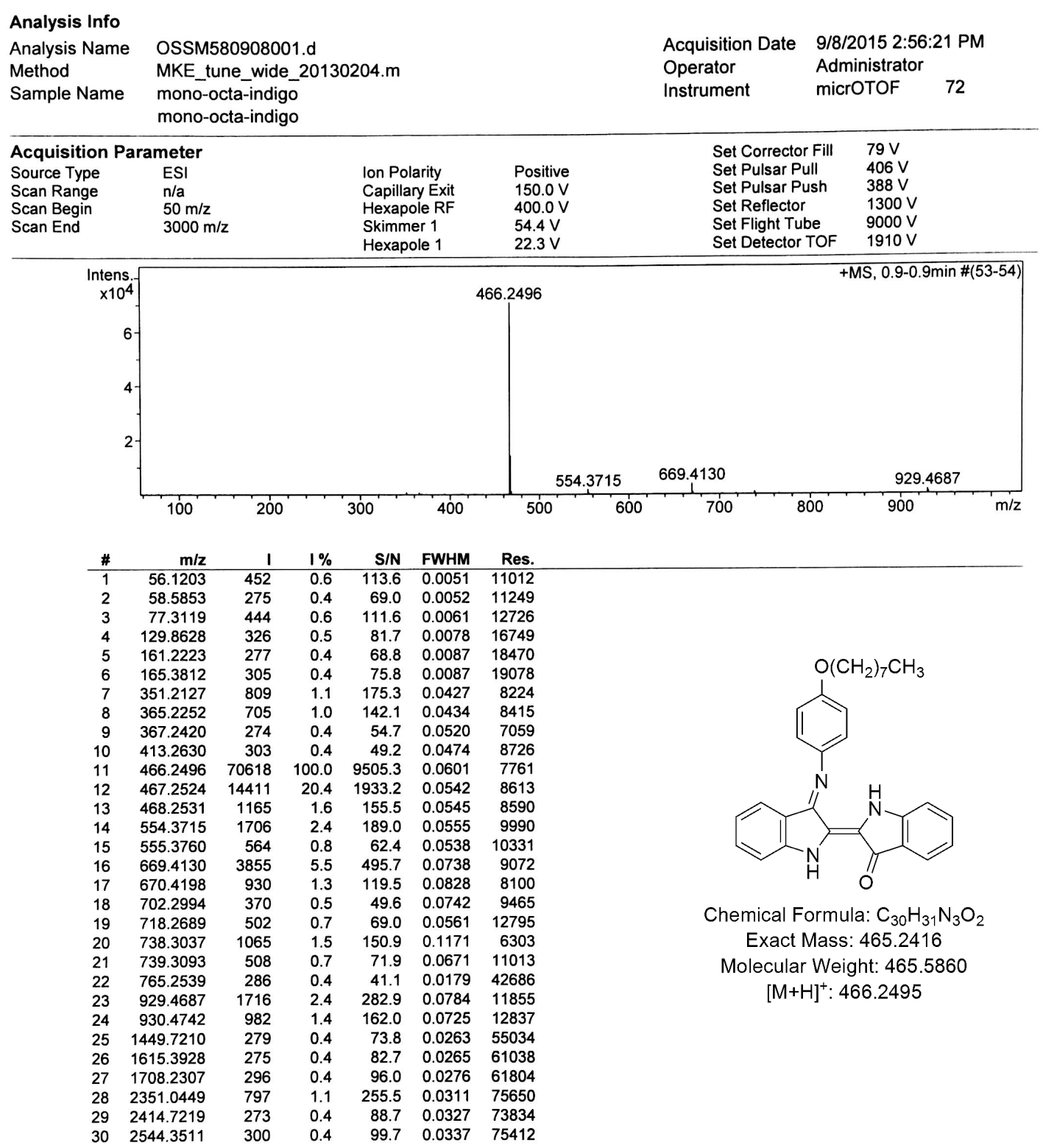

Figure S3. HR-ESI mass spectrum of compound 1 


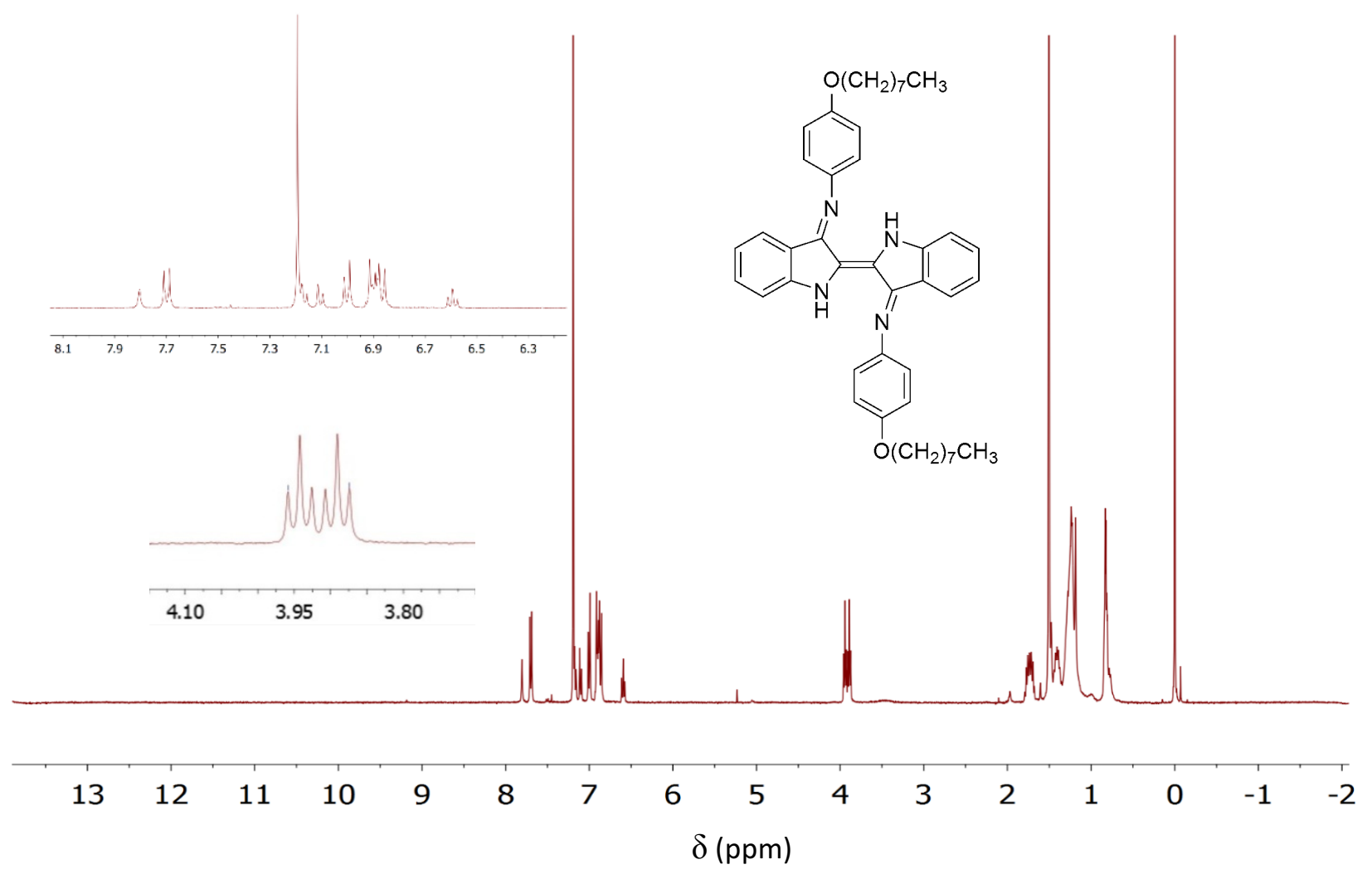

Figure S4. 'H-NMR spectrum of compound 2 in $\mathrm{CDCl}_{3}$

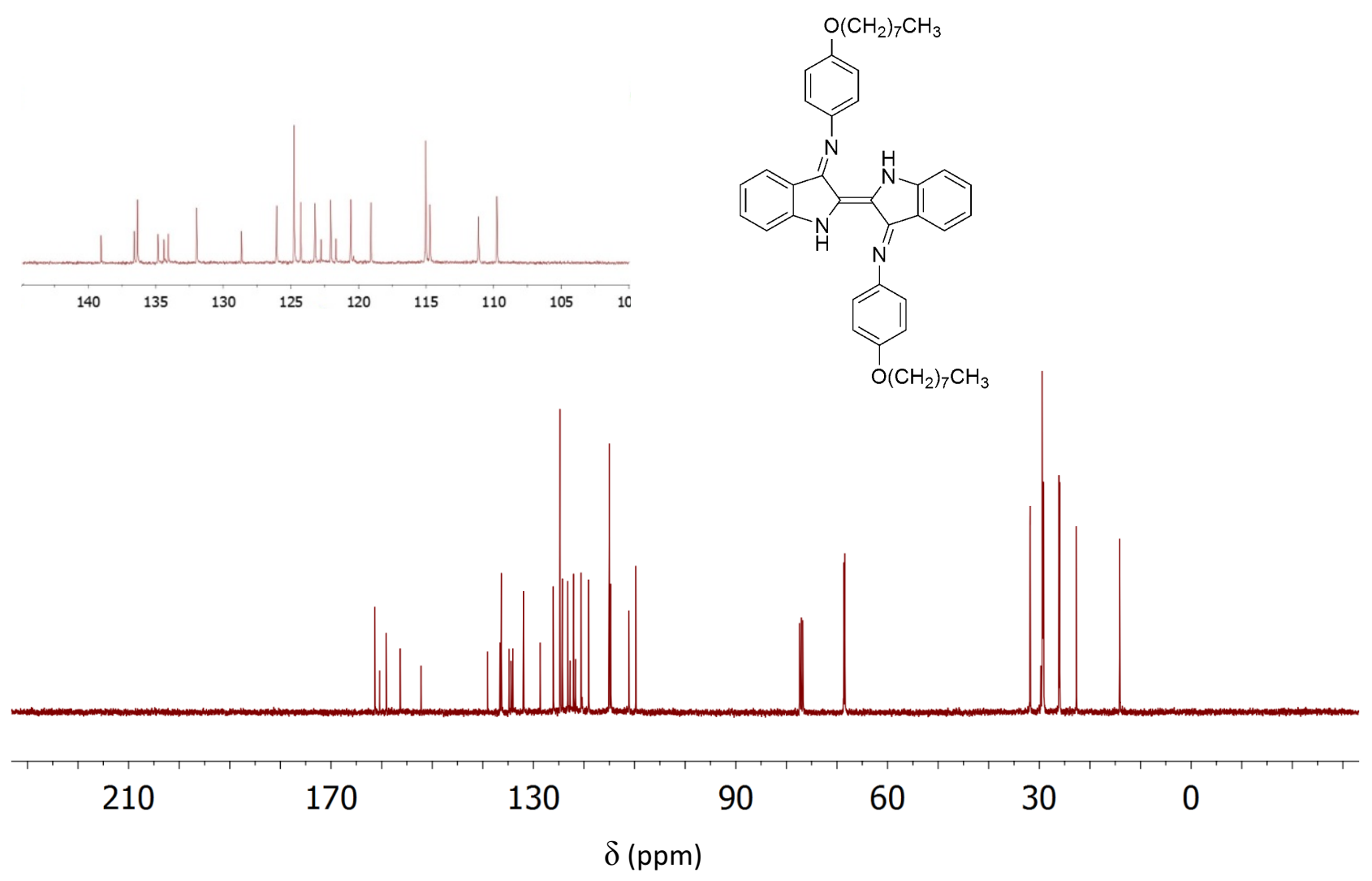

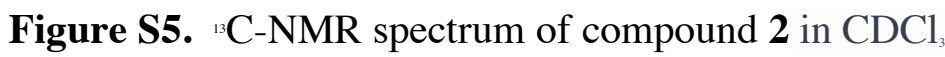




\section{Mass Spectrum List Report}

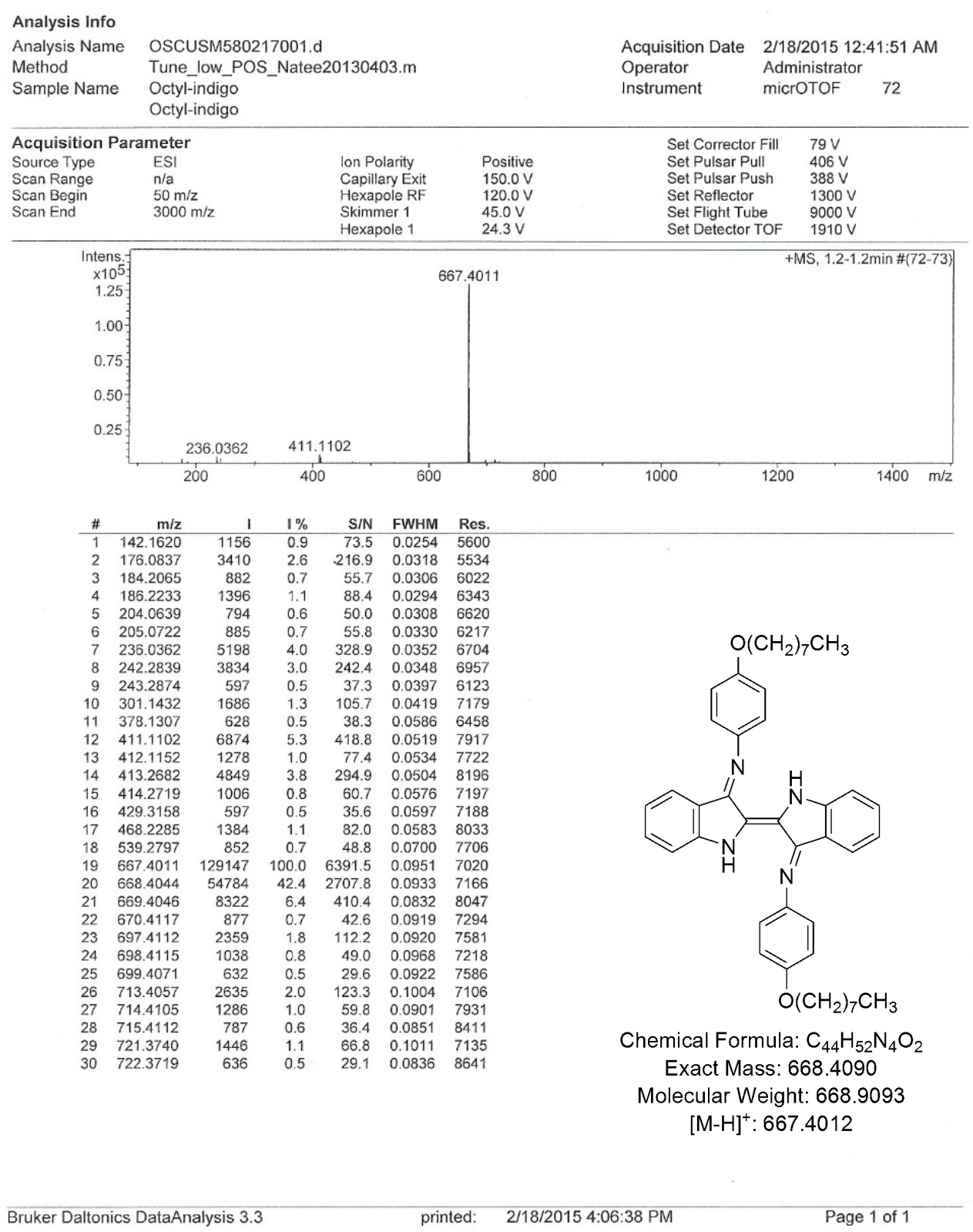

Figure S6. HR-ESI mass spectrum of compound 2 

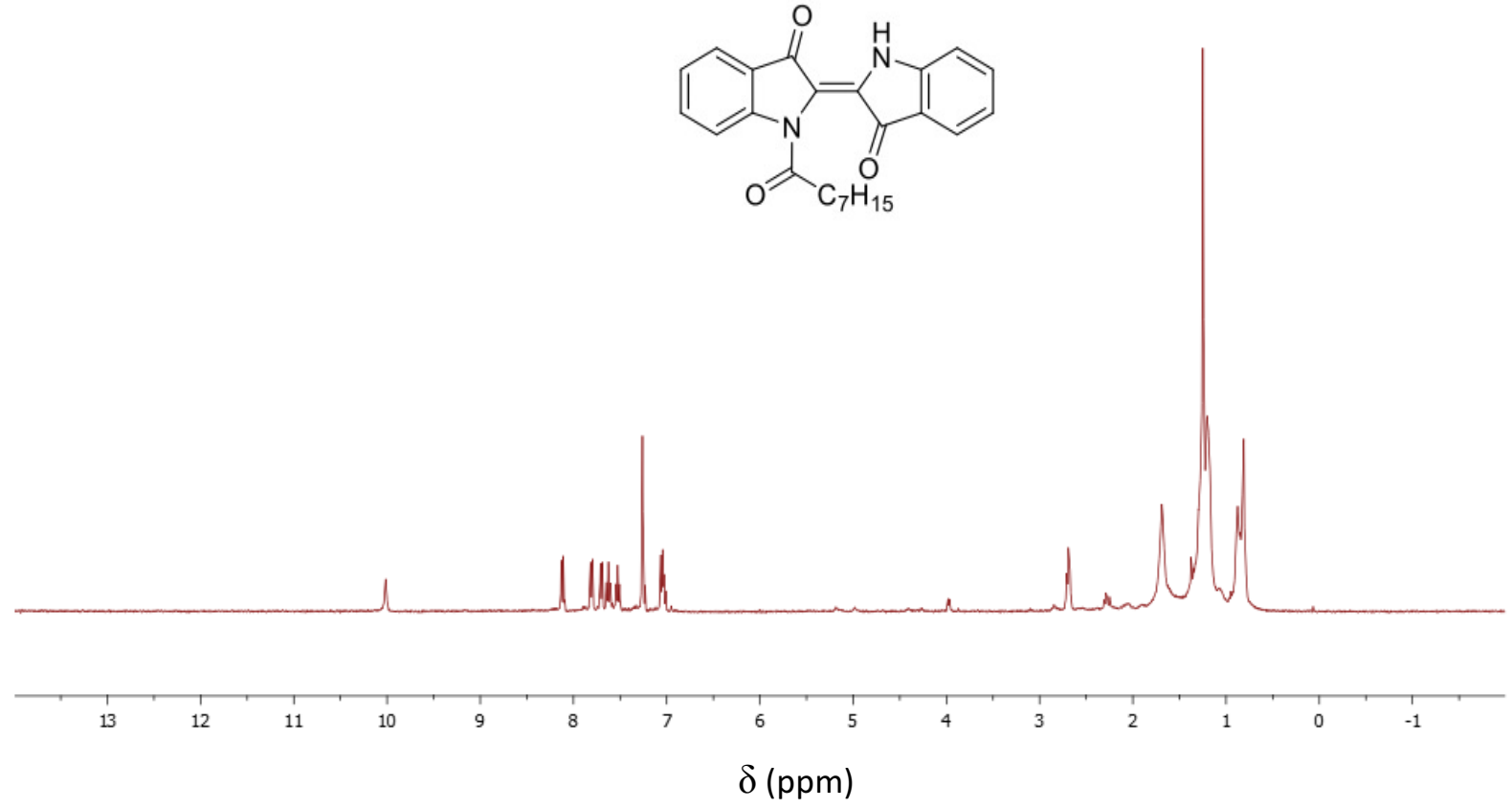

Figure S7. $\mathrm{H}-\mathrm{NMR}$ spectrum of compound 3 in $\mathrm{CDCl}_{3}$<smiles>CCC(=O)N1C(=C2Nc3ccccc3C2=O)C(=O)c2ccccc21</smiles>

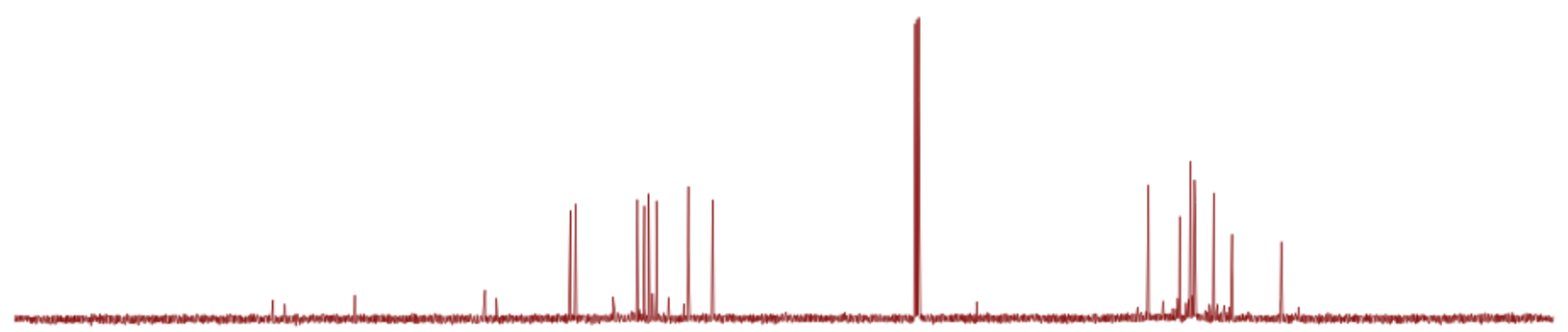

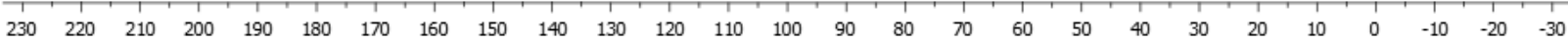
$\delta(\mathrm{ppm})$

Figure S8. ${ }^{\mathrm{C}}$-NMR spectrum of compound 3 in $\mathrm{CDCl}_{3}$ 


\section{Mass Spectrum List Report}

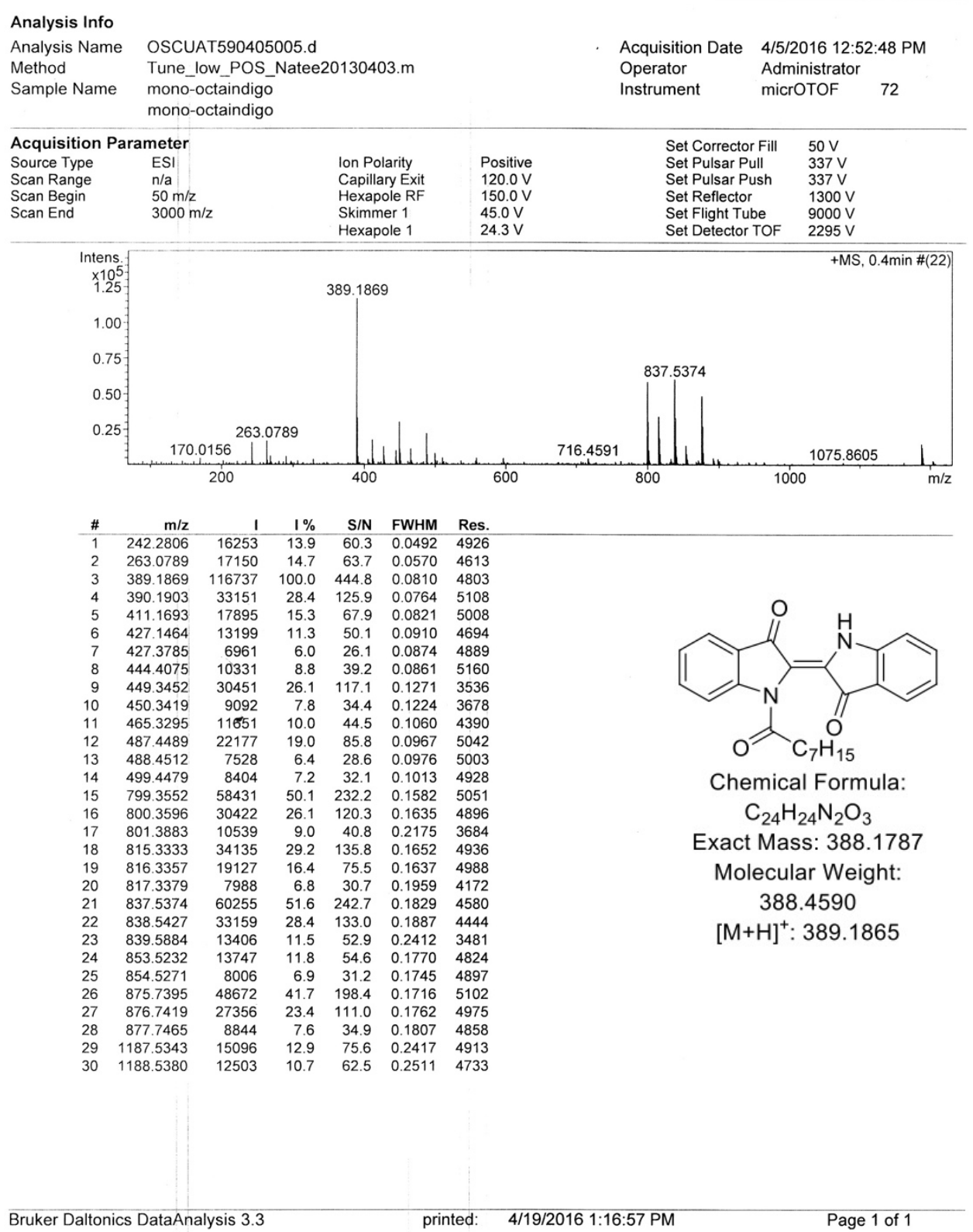

Figure S9. HR-ESI mass spectrum of compound $\mathbf{3}$ 
<smiles>CC(C)C(=O)N1/C(=C2\C(=O)c3ccccc3N2C(=O)C(C)S)C(=O)c2ccccc21</smiles>

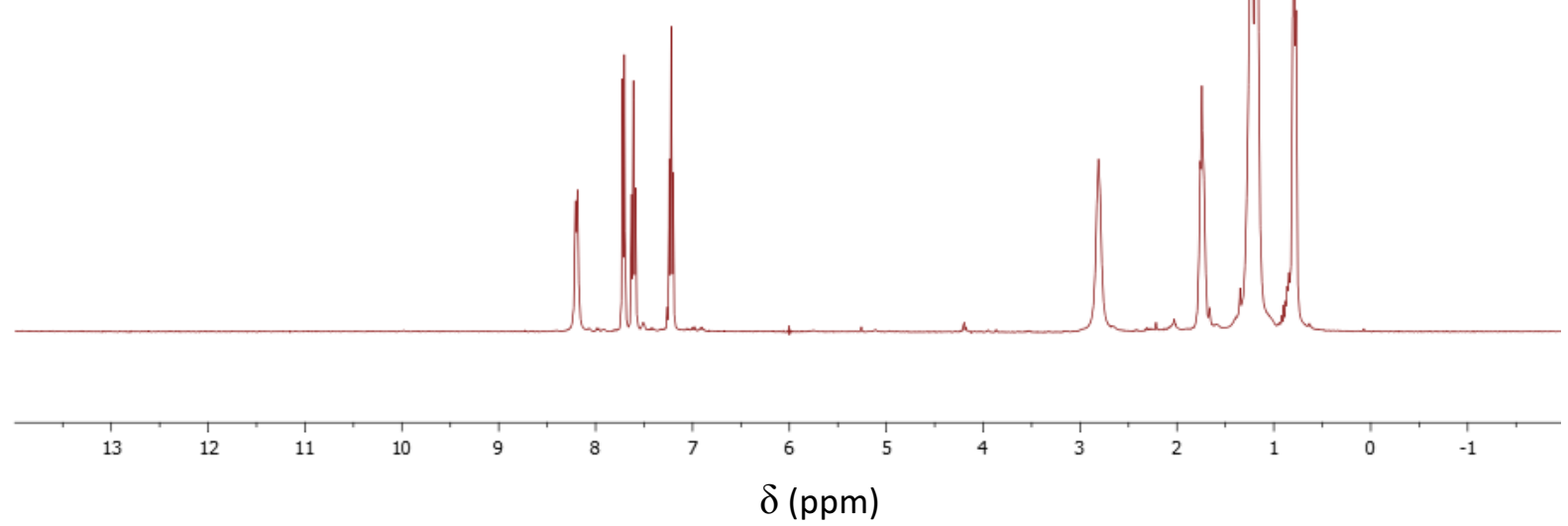

Figure S10. 'H-NMR spectrum of compound 4 in $\mathrm{CDCl}_{3}$

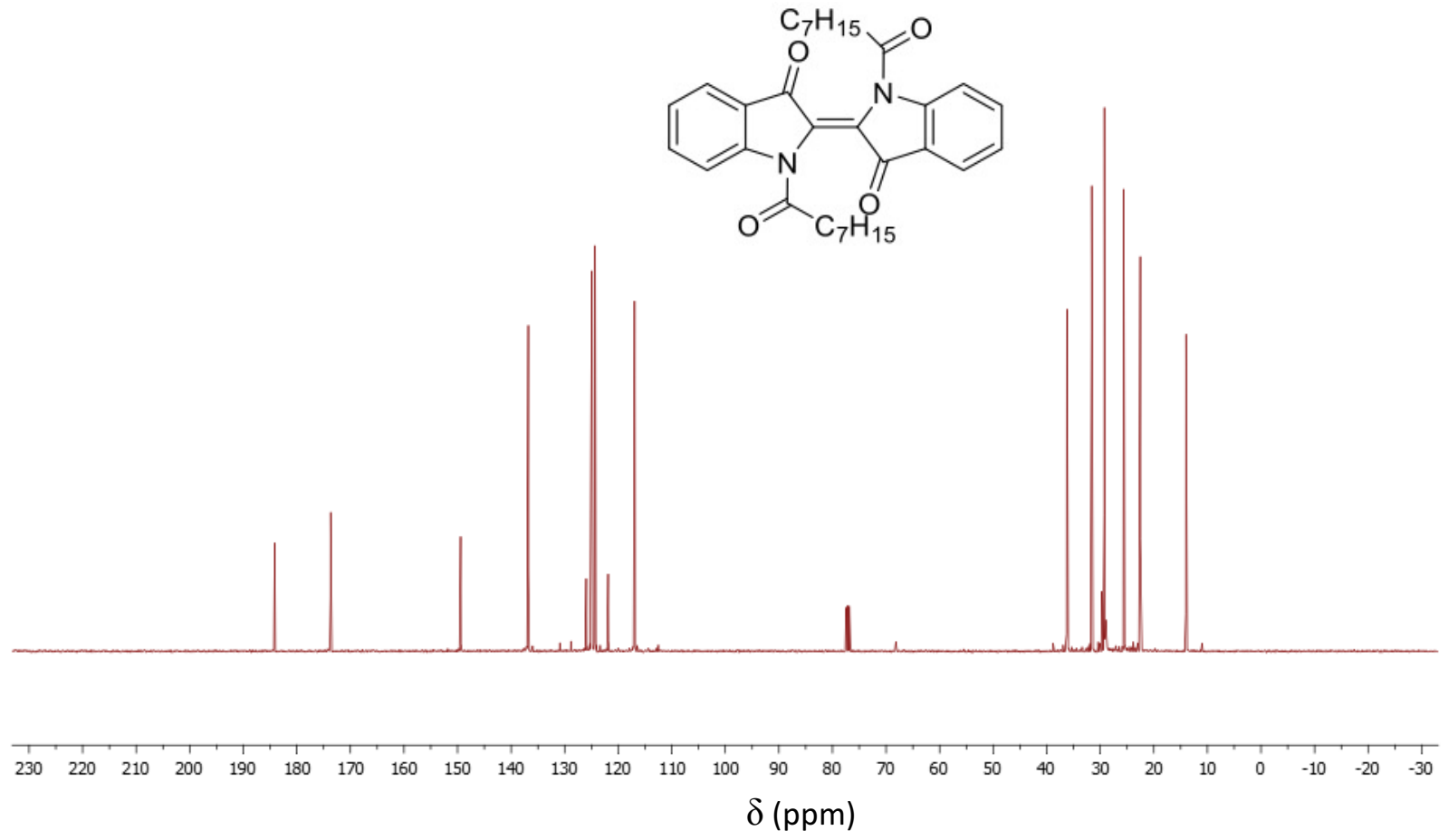

Figure S11. ${ }^{\mathrm{C}} \mathrm{C}-\mathrm{NMR}$ spectrum of compound 4 in $\mathrm{CDCl}_{3}$ 


\section{Mass Spectrum List Report}

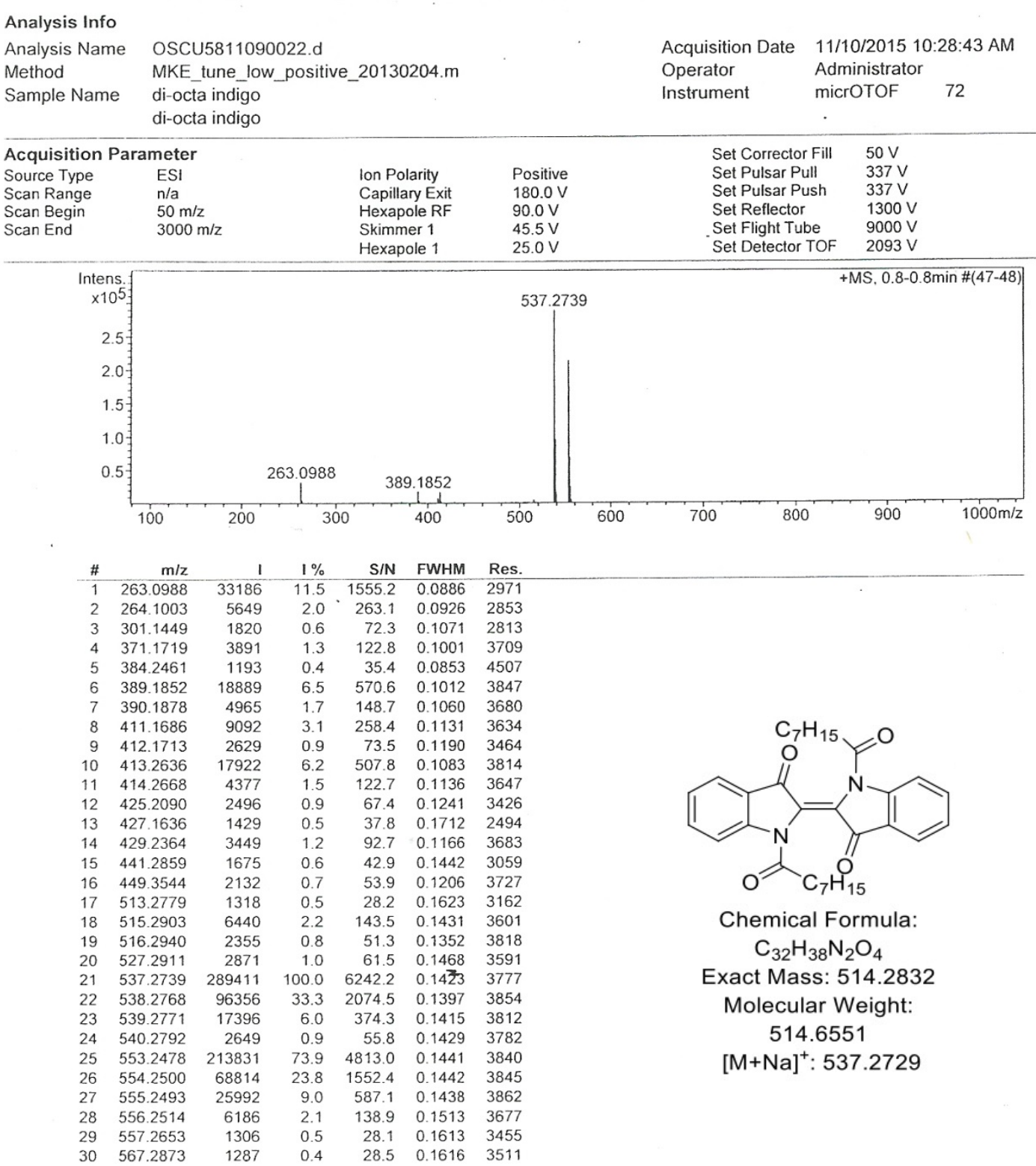

Figure S12. HR-ESI mass spectrum of compound 4 
<smiles>CC(C)C(=O)N1/C(=C2\Nc3ccccc3C2=O)C(=O)c2ccccc21</smiles>
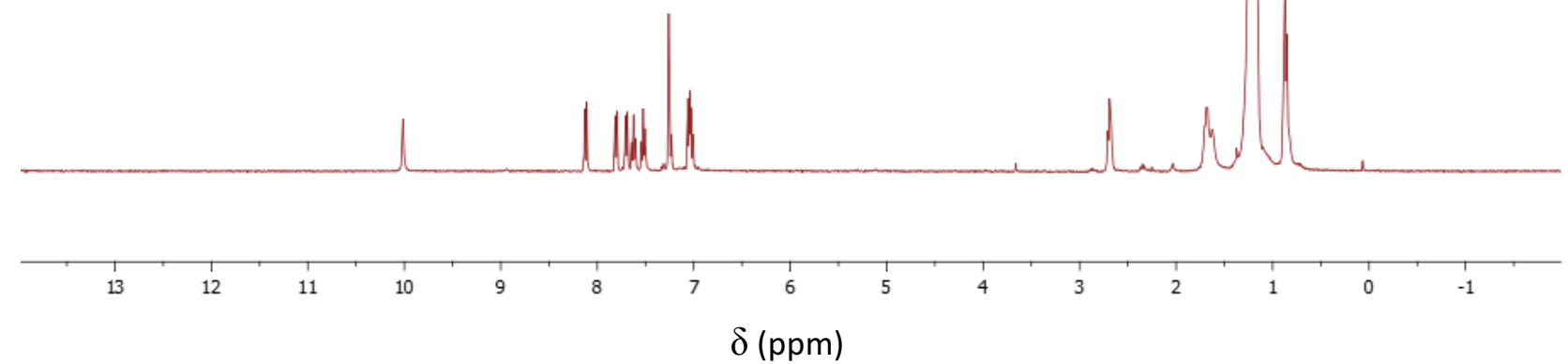

Figure S13. $\mathrm{H}-\mathrm{NMR}$ spectrum of compound 5 in $\mathrm{CDCl}_{3}$<smiles>CC(C)C(=O)N1C(=C2Nc3ccccc3C2=O)C(=O)c2ccccc21</smiles>
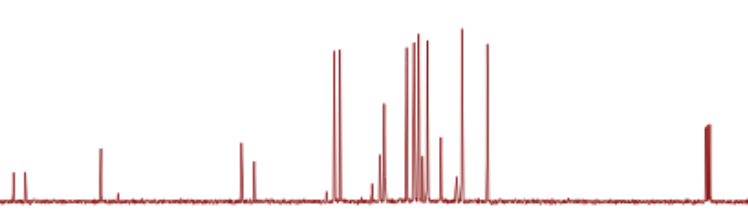

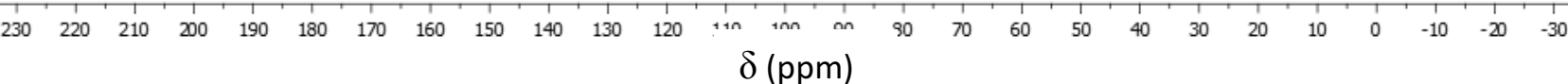

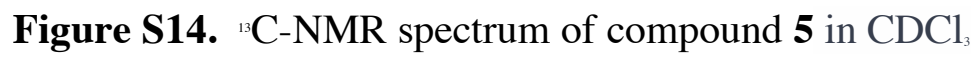




\section{Mass Spectrum List Report}

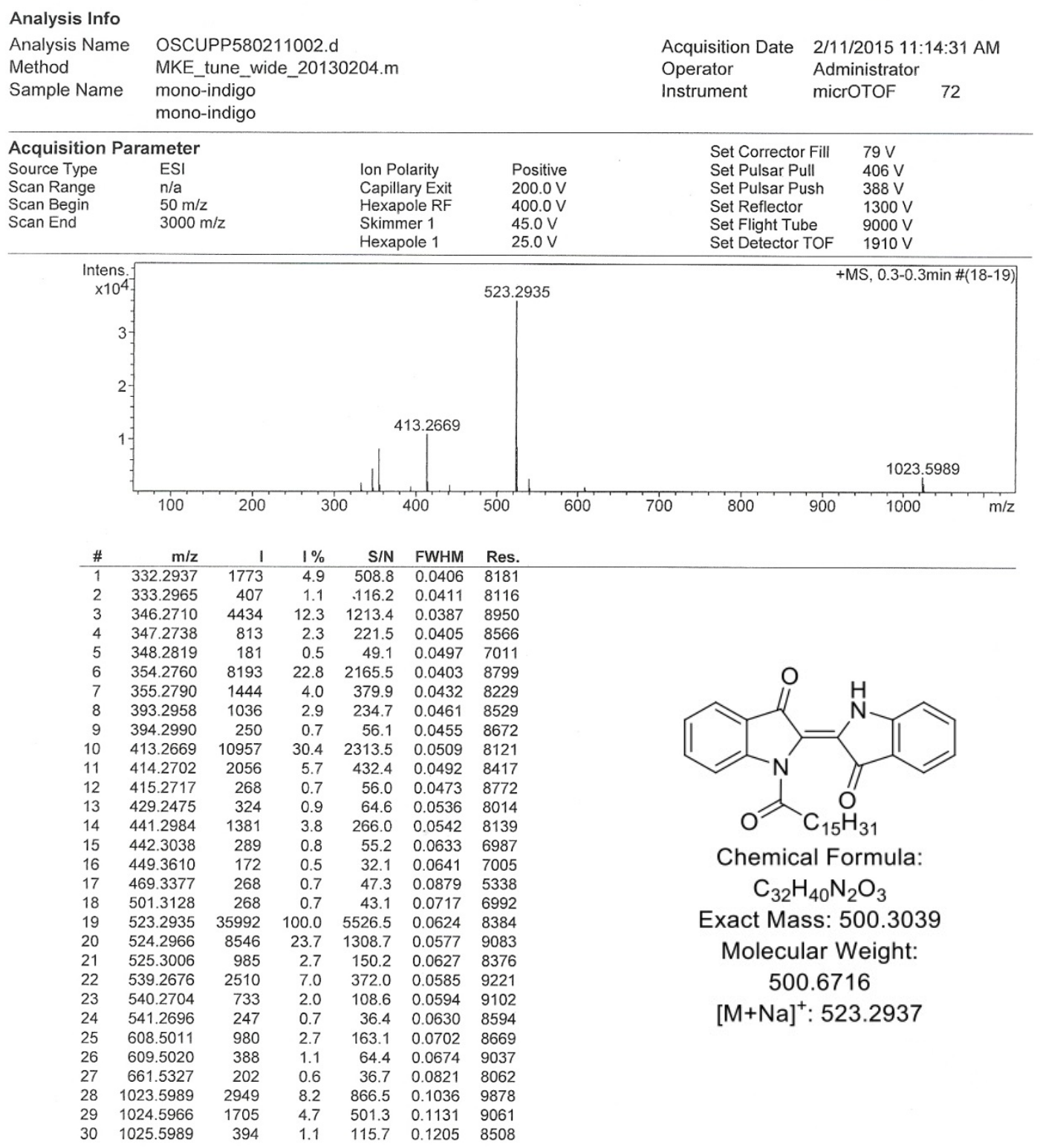

Figure S15. HR-ESI mass spectrum of compound $\mathbf{5}$ 
<smiles>CC(=O)N1/C(=C2\C(=O)c3ccccc3N2C([13CH3])=O)C(=O)c2ccccc21</smiles>

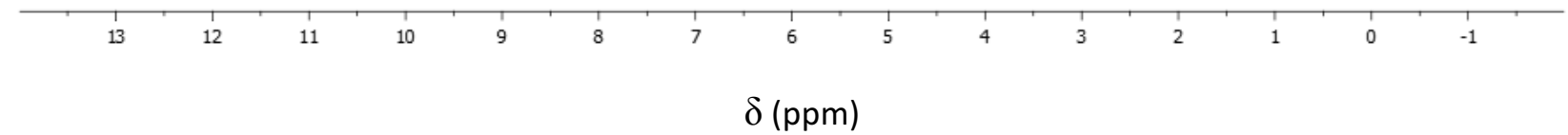

Figure S16. 'H-NMR spectrum of compound 6 in $\mathrm{CDCl}_{3}$<smiles>CC(=O)N1C(=C2C(=O)c3ccccc3N2C([13CH3])=O)C(=O)c2ccccc21</smiles>

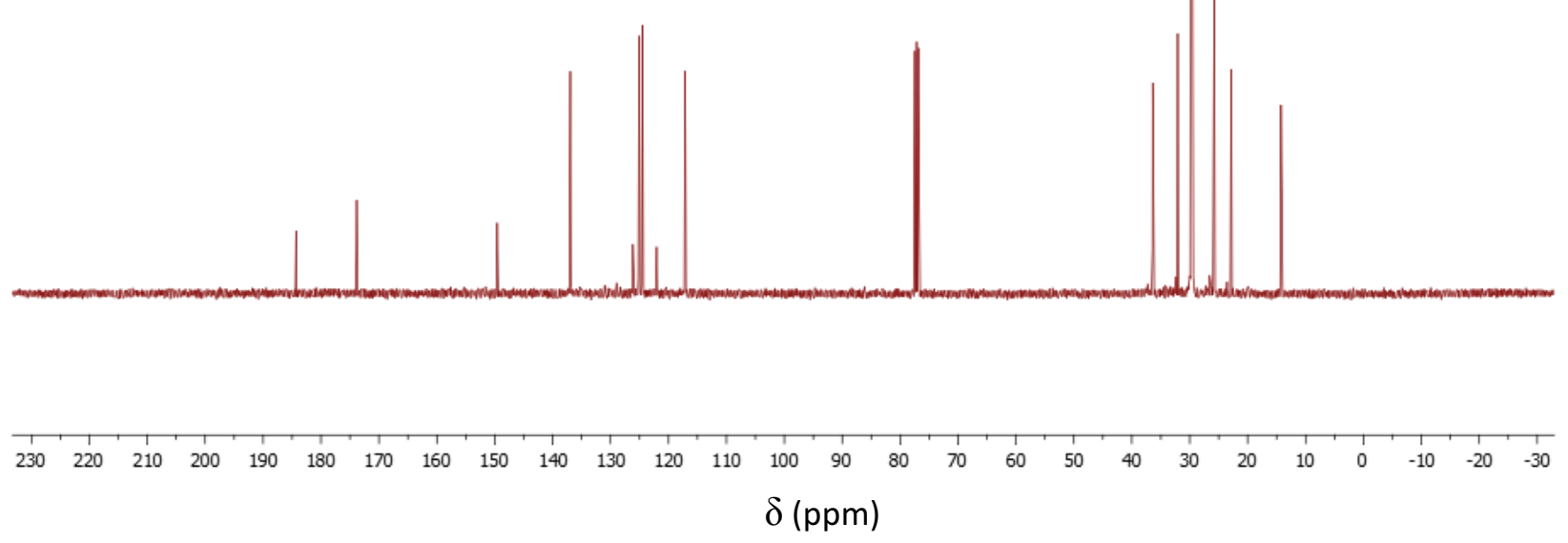

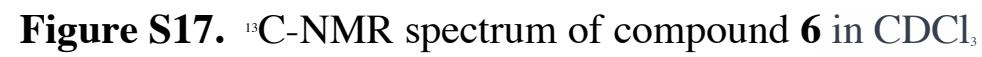




\section{Mass Spectrum List Report}

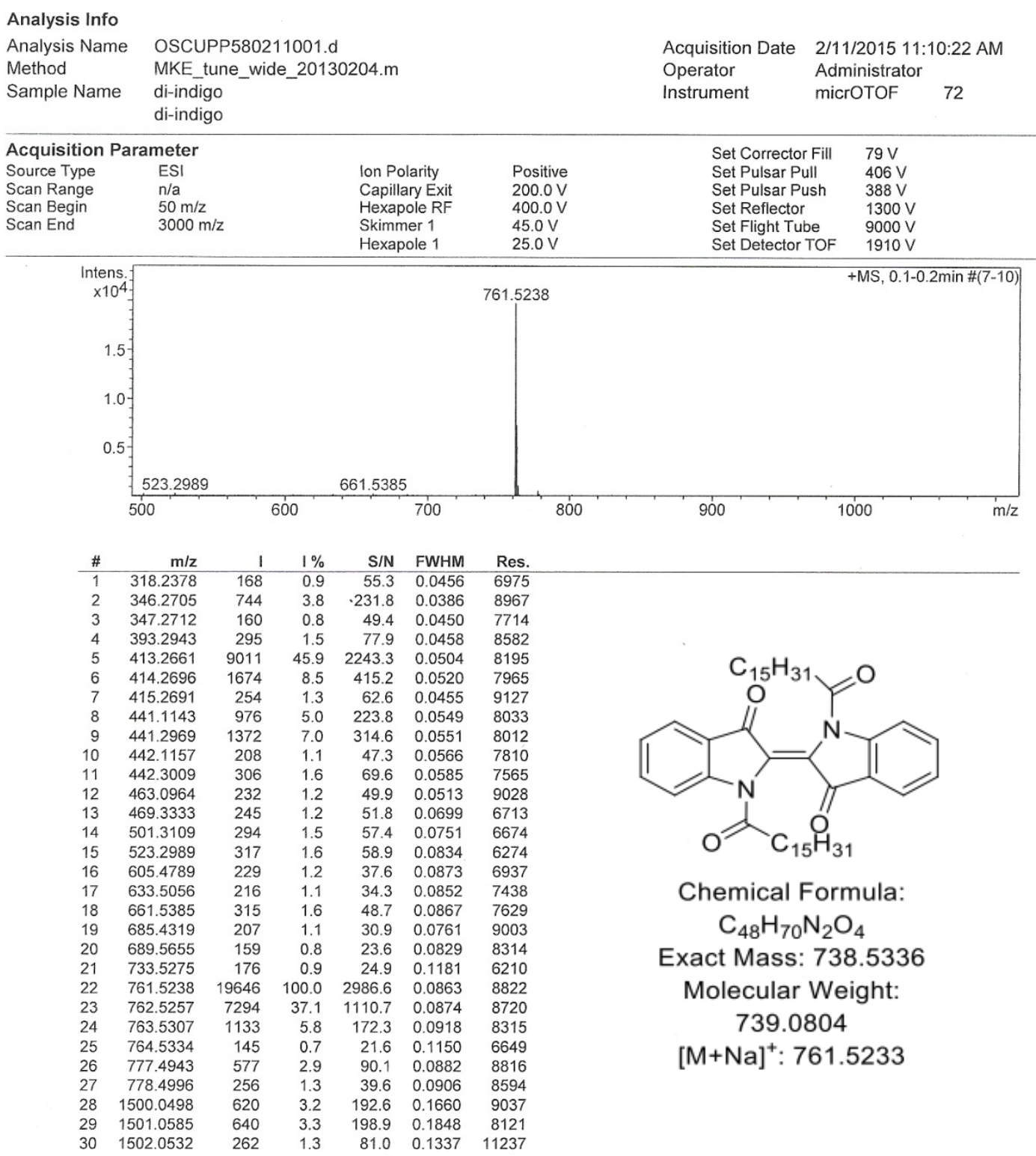

Figure S18. HR-ESI mass spectrum of compound 6 


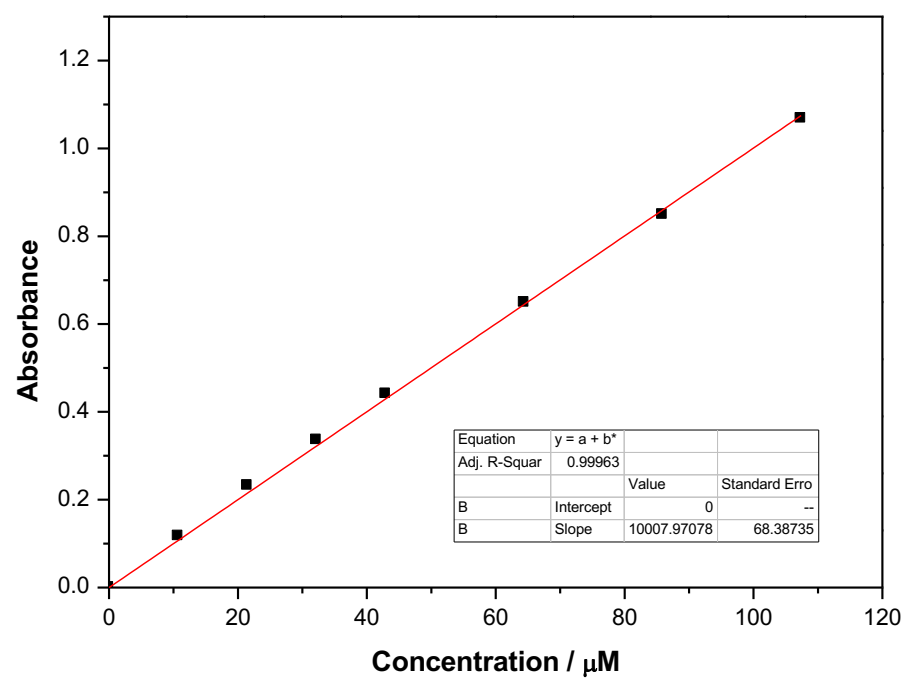

Figure S19. Standard calibration curve of compound 1 in toluene at $595 \mathrm{~nm}$

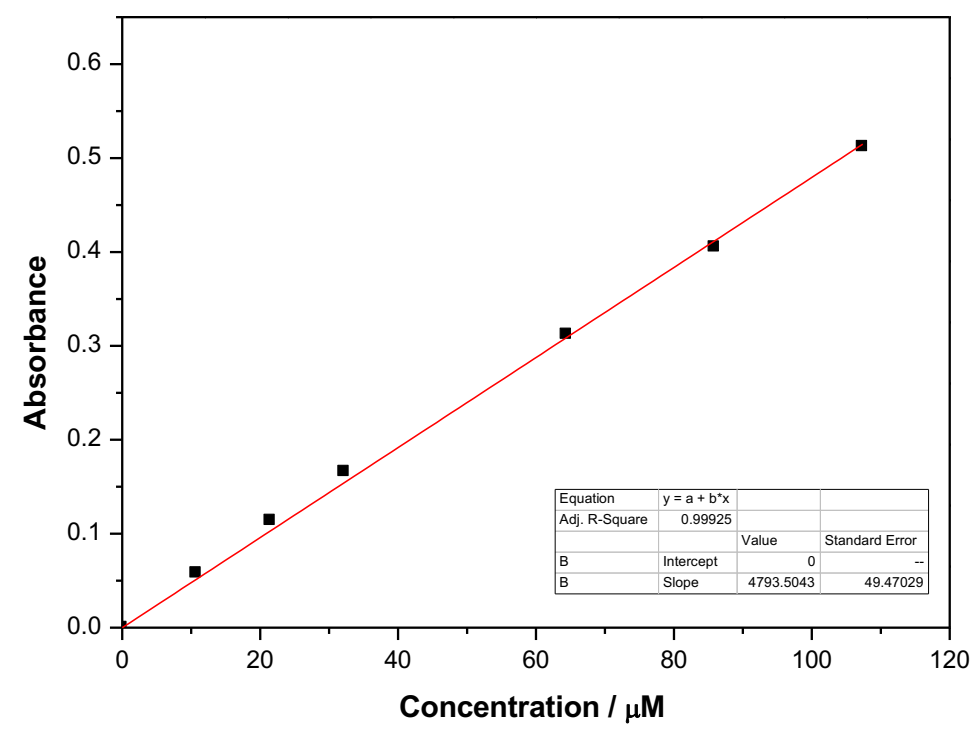

Figure S20. Standard calibration curve of compound 1 in diesel at $590 \mathrm{~nm}$ 


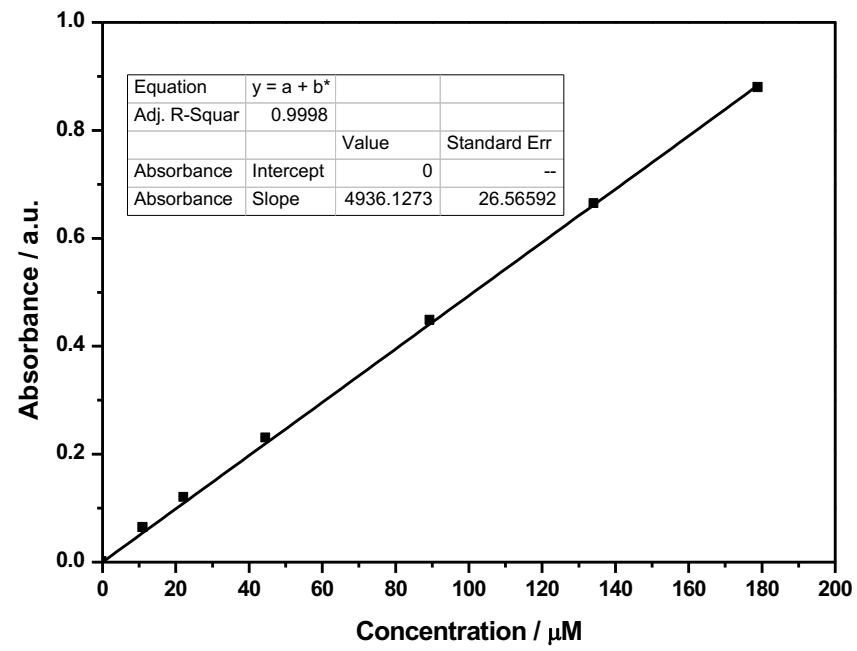

Figure S21. Standard calibration curve of compound $\mathbf{3}$ in toluene at $575 \mathrm{~nm}$

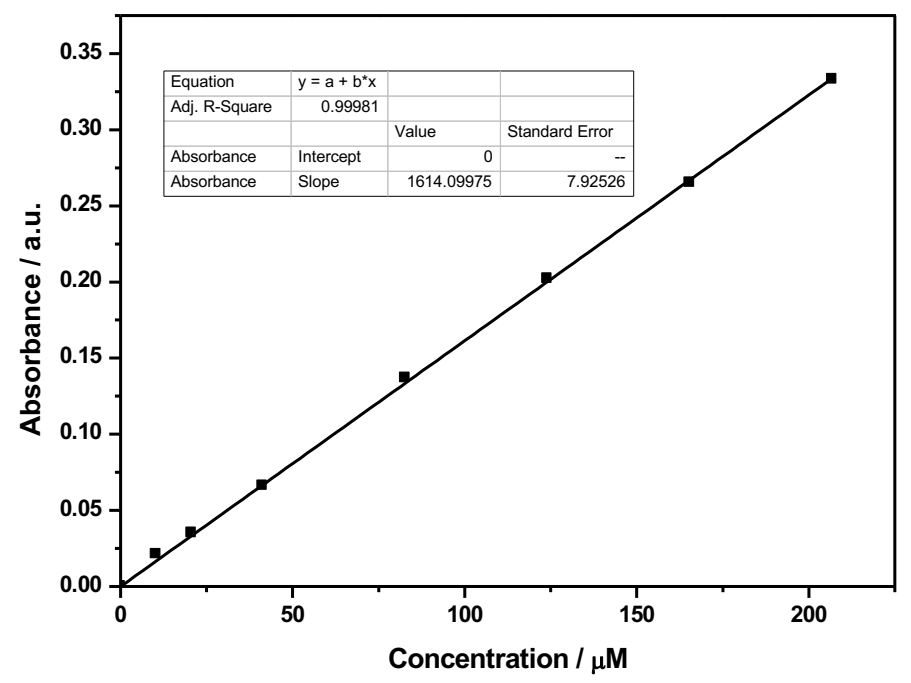

Figure S22. Standard calibration curve of compound 3 in diesel at $570 \mathrm{~nm}$ 


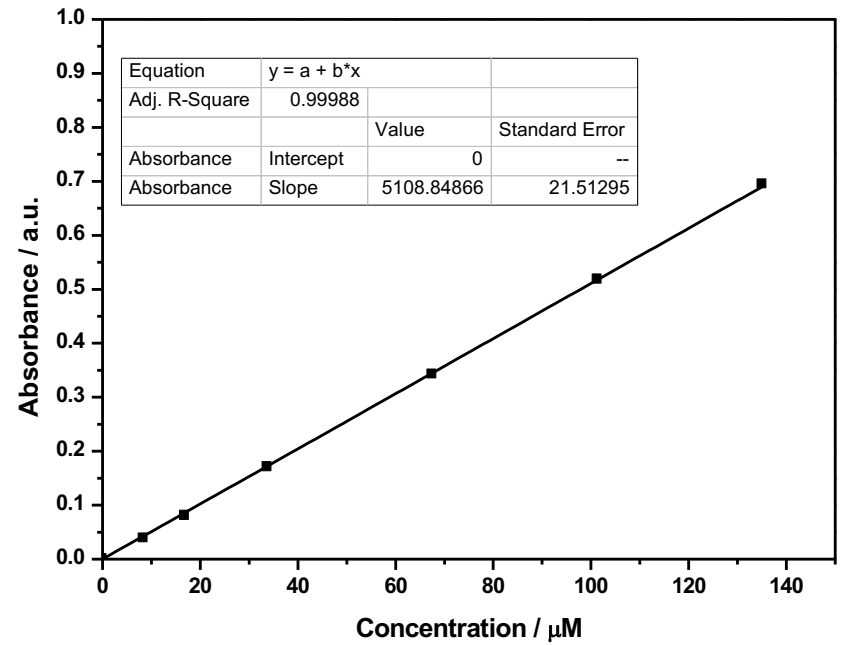

Figure S23. Standard calibration curve of compound 4 in toluene at $570 \mathrm{~nm}$

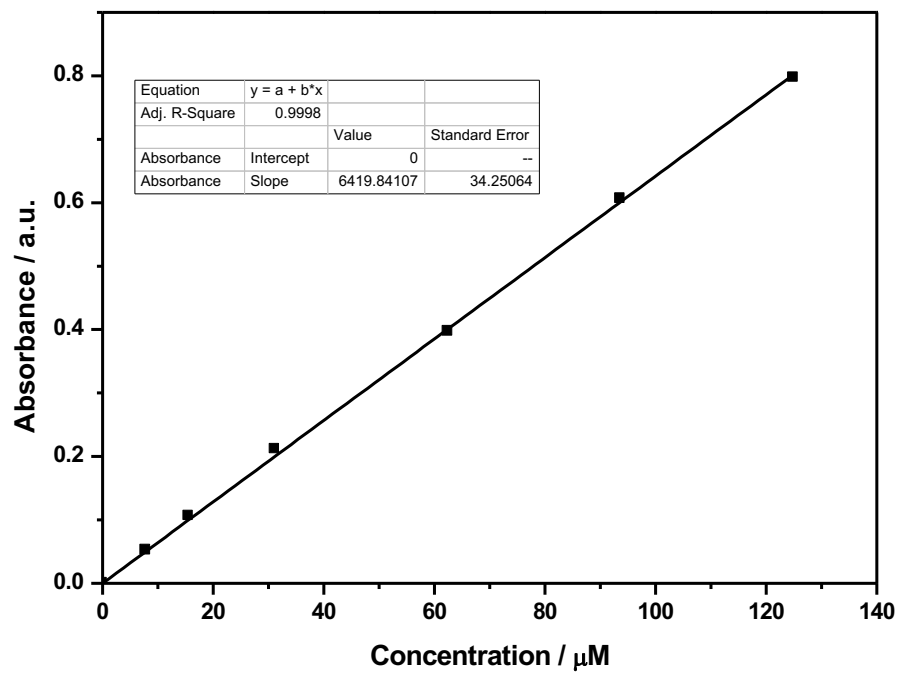

Figure S24. Standard calibration curve of compound 4 in diesel at $570 \mathrm{~nm}$ 


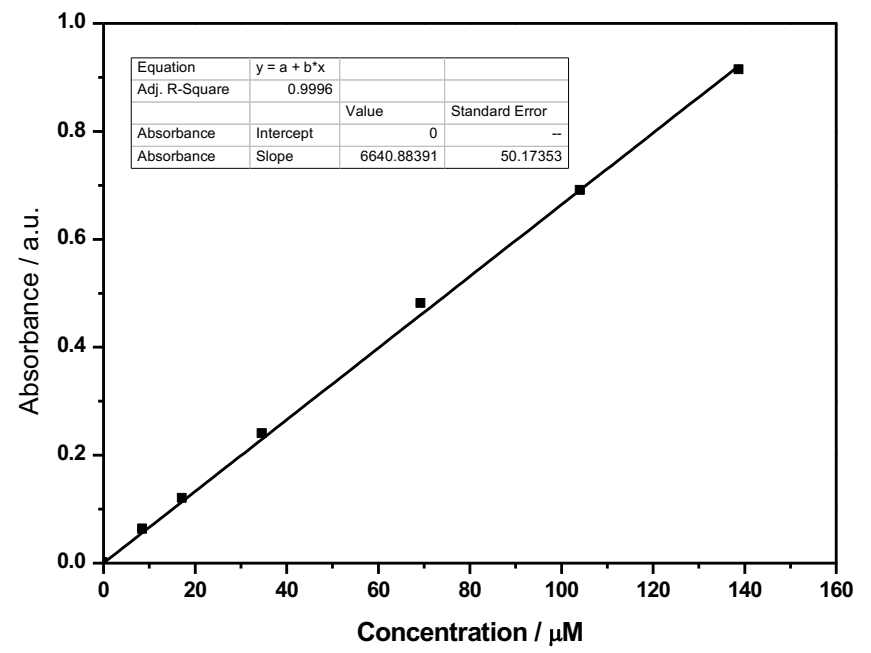

Figure S25. Standard calibration curve of compound 5 in toluene at $575 \mathrm{~nm}$

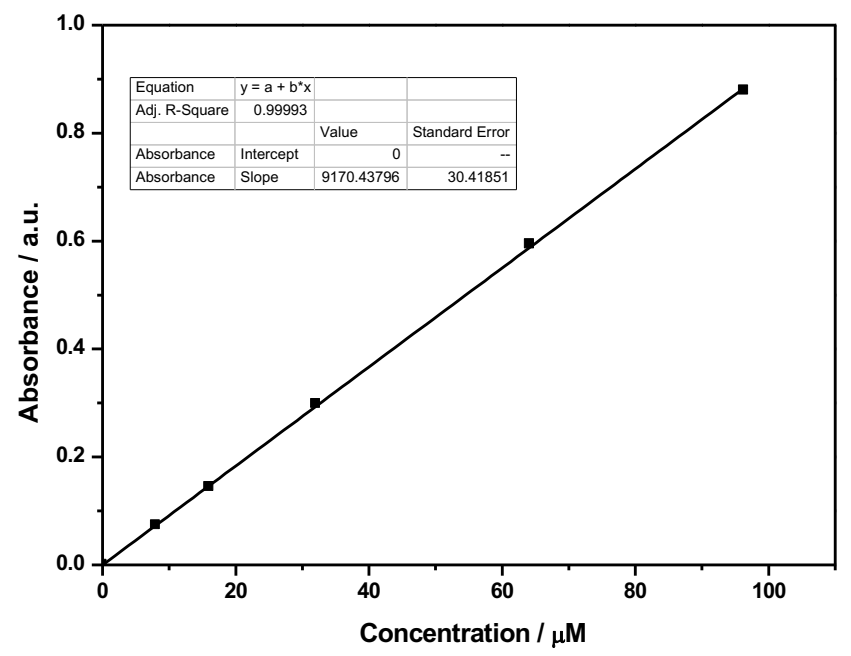

Figure S26. Standard calibration curve of compound 5 in diesel at $575 \mathrm{~nm}$ 


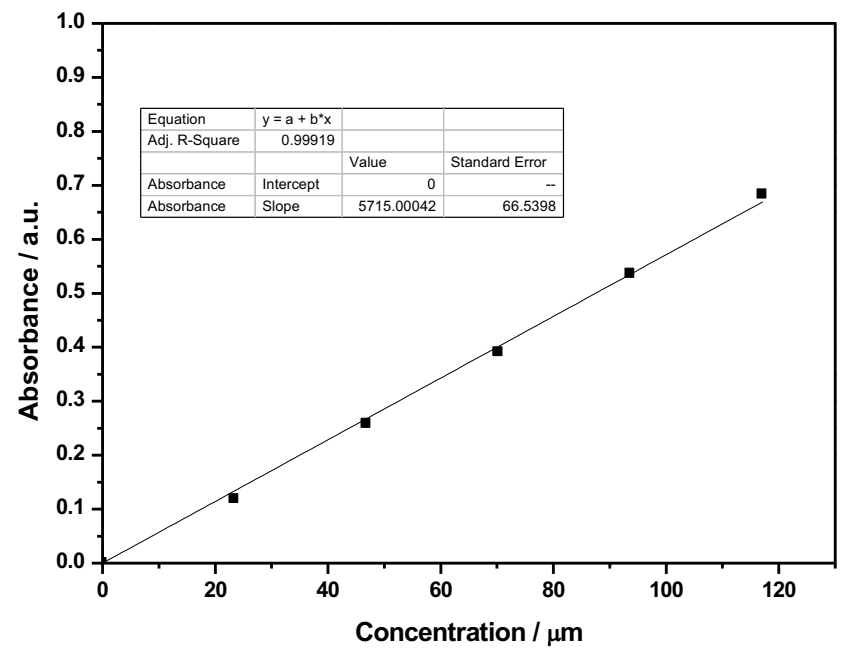

Figure S27. Standard calibration curve of compound 6 in toluene at $570 \mathrm{~nm}$

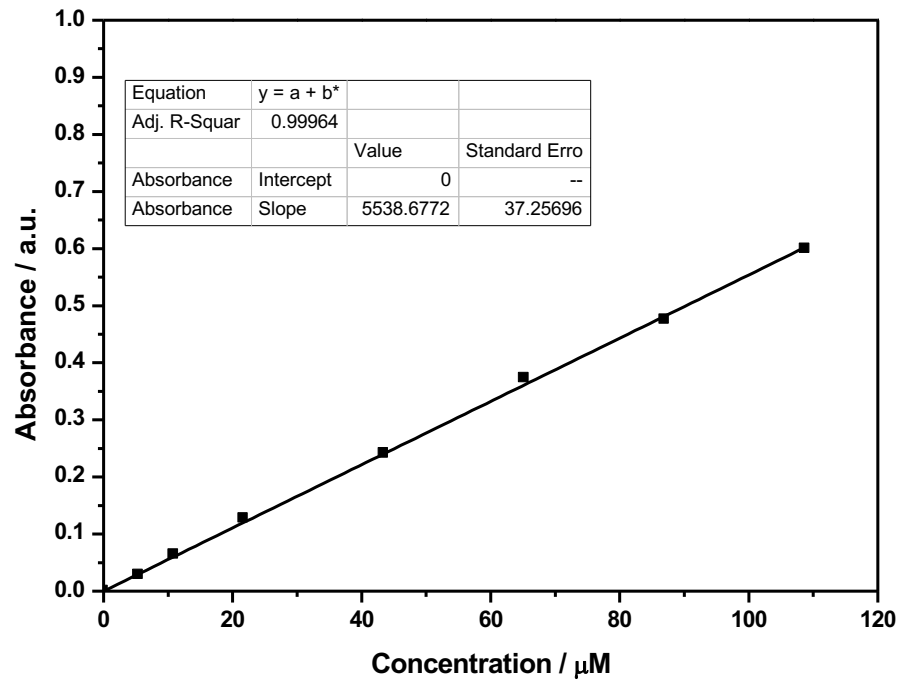

Figure S28. Standard calibration curve of compound 6 in diesel at $570 \mathrm{~nm}$ 